\title{
Adhesion dynamics of Flavobacterium columnare to channel catfish Ictalurus punctatus and zebrafish Danio rerio after immersion challenge
}

\author{
Oscar Olivares-Fuster ${ }^{1}$, Stephen A. Bullard ${ }^{2}$, Andrew McElwain ${ }^{2}$, Maria Jose Llosa ${ }^{3}$, \\ Covadonga R. Arias ${ }^{1, *}$

\begin{abstract}
${ }^{1}$ Aquatic Microbiology Laboratory and ${ }^{2}$ Parasitology Laboratory, Department of Fisheries and Allied Aquacultures, Auburn University, 203 Swingle Hall, Auburn University, Auburn, Alabama 36849, USA

${ }^{3}$ Instituto Valenciano de Investigaciones Agrarias, Carretera Moncada-Naquera S/N, Valencia, Spain
\end{abstract}

\begin{abstract}
The adhesion dynamics of Flavobacterium columnare to fish tissues were evaluated in vivo by immersion challenge followed by bacterial plate count and confirmatory observations of gilladhered bacterial cells using scanning electron microscopy. Adhesion of $F$. columnare genomovar I (ARS-1) and II (BGFS-27) strains to skin and gill of channel catfish Ictalurus punctactus and gill of zebrafish Danio rerio was compared. At $0.5 \mathrm{~h}$ post-challenge, both strains adhered to gill of channel catfish at comparable levels $\left(10^{6}\right.$ colony forming units [CFU] $\left.\mathrm{g}^{-1}\right)$, but significant differences in adhesion were found later in the time course. Channel catfish was able to effectively reduce ARS-1 cells on gill, whereas BGFS-27 persisted in gill beyond the first $24 \mathrm{~h}$ post-challenge. No significant difference was found between both strains when adhered to skin, but adhered cell numbers were lower $\left(10^{3} \mathrm{CFU} \mathrm{g}{ }^{-1}\right)$ than those found in gill and were not detectable at $6 \mathrm{~h}$ post-challenge. Adhesion of BGFS-27 cells to gill of zebrafish also occurred at high numbers $\left(>10^{6} \mathrm{CFU} \mathrm{g}^{-1}\right)$, while only $<10^{2} \mathrm{CFU}$ $\mathrm{g}^{-1}$ of ARS-1 cells were detected in this fish. The results of the present study show that particular strains of $F$. columnare exhibit different levels of specificity to their fish hosts and that adhesion to fish tissues is not sufficient to cause columnaris disease
\end{abstract}

KEY WORDS: Adhesion - Columnaris disease $\cdot$ Flavobacterium columnare $\cdot$ Host-pathogen specificity

\section{INTRODUCTION}

Flavobacterium columnare is a Gram-negative bacterium belonging to the Cytophaga-FlavobacteriumBacteroides (CFB) group and the causative agent of columnaris disease (Bernardet et al. 1996). It has a cosmopolitan distribution in temperate and tropical latitudes and has been isolated from an ecologically and phylogenetically diverse spectrum of wild-caught, aquaculture-reared, and ornamental freshwater fishes (Triyanto \& Wakabayashi 1999, Schneck \& Caslake 2006, Olivares-Fuster et al. 2007). Given the nexus of appropriate host and environmental factors, columnaris disease can be economically devastating for the channel catfish Ictalurus punctatus (Rafinesque, 1818) aquaculture industry where in-pond mortality rates among adults and fingerlings can reach 60 and $90 \%$, respectively (Plumb 1999).

Flavobacterium columnare presently is classified into 3 distinct genomic groups or genomovars (Triyanto \& Wakabayashi 1999), with genomovar II being more virulent to catfish than genomovar I (Shoemaker et al. 2008). Recently, Klesius et al. (2008) reported that genomovar II isolates were more strongly chemotactic to channel catfish mucus than genomovar I isolates. In addition, Shoemaker et al. (2008) showed a positive correlation between virulence and 
adherence in channel catfish fry when challenged with $F$. columnare. It is plausible that genomovar II strains could more efficiently adhere to the epithelial tissues and mucus coverings of catfishes such that intense infections and subsequent manifestation of columnaris disease are more likely. However, the relationship between adhesion of $F$. columnare cells and virulence is not clear at this point with some studies supporting a positive correlation (Decostere et al. 1999a,b) while others found no such association (Kunttu et al. 2009). Herein, we studied the dynamics of adhesion of genomovar I and II strains in channel catfish and zebrafish Danio rerio (Hamilton, 1822) after exposure to $F$. columnare by immersion bath. We included zebrafish as a common experimental organism that is susceptible to columnaris disease (Moyer \& Hunnicutt 2007).

\section{MATERIALS AND METHODS}

Fish husbandry. Specific pathogen free (SPF) channel catfish fingerlings $(\mathrm{n}=180$; mean weight $=4.2 \mathrm{~g})$ were obtained from the School of Veterinary Medicine at Auburn University, transferred to the Aquatic Microbiology Laboratory, and stocked into 371 aquaria at 15 fish per tank. Similarly, non-sexed adult zebrafish $(\mathrm{n}=360$, mean weight $=0.6 \mathrm{~g})$ were purchased from Aquatica Tropicals (Plant City, FL, USA), transferred to the Aquatic Microbiology Laboratory, and stocked into 371 aquaria at 30 fish per tank. Prior to stocking, 10 randomly selected fish from each species were microbiologically examined and proved culture-negative for the presence of Flavobacterium columnare. Channel catfish and zebrafish were fed daily to apparent satiation with AQUAMAX Grower 400 (Purina Mills) and $41 \%$ crude protein flakes (Central Garden and Pet), respectively. Each aquarium was equipped with a biofilter and air stone, and supplied with artificial freshwater $(80 \mathrm{ppm}$ alkalinity, $40 \mathrm{ppm}$ hardness, $0.1 \mathrm{ppt}$ salinity). Temperature was kept at $27 \pm 1^{\circ} \mathrm{C}$ and $\mathrm{pH} 7.8$ $\pm 0.2($ mean $\pm \mathrm{SE})$, and fish were subjected to a $12 \mathrm{~h}$ photoperiod. Water parameters were checked daily. Ammonia and nitrite levels were non-detectable throughout the study.

Bacterial strains maintenance. Two previously-identified strains of Flavobacterium columnare, ARS-1 (genomovar I) and BGFS-27 (genomovar II), were used herein (Arias et al. 2004). Both strains were originally isolated from channel catfish and experimental challenges have shown ARS-1 as a low virulence strain, while BGFS-27 is proved to be highly virulent in channel catfish (Shoemaker et al. 2008). Stock suspensions of all isolates were stored in $10 \%$ glycerol at $-80^{\circ} \mathrm{C}$. Strains were routinely cultured in modified Shieh broth (Shoemaker et al. 2005) for $24 \mathrm{~h}$ at $26^{\circ} \mathrm{C}$ with gentle shaking.

Challenge experiments. A total of 4 challenge experiments were conducted, 2 with each fish species. Expts 1 and 2 used channel catfish, while Expts 3 and 4 used zebrafish. Expt 1 assessed bacterial cell adhesion to gill and skin, and Expts 2, 3, and 4 assessed bacterial cell adhesion to gill only. Each consisted of 2 treatments (ARS-1 and BGFS-27) and one control. Each treatment consisted of 3 randomized replicates (tanks). The immersion challenge was carried out as described by Shoemaker et al. (2008) with the following modifications: 15 channel catfish per treatment or 30 zebrafish per treatment were challenged with an overnight culture of the corresponding bacterial treatment (i.e. ARS- 1 or BGFS-27) at approximately $5 \times 10^{6}$ colony forming units (CFU) $\mathrm{ml}^{-1}$. Negative controls were exposed to modified Shieh broth without bacteria. After a $0.5 \mathrm{~h}$ challenge, fish were returned to their individual aquaria and monitored at $12 \mathrm{~h}$ intervals for abnormal behavior, loss of appetite, and mortality. Moribund fish were sampled for Flavobacterium columnare following standard protocols.

Quantification of bacterial adhesion. Immediately before challenge and at $0.5,1,6,12$, and $24 \mathrm{~h}$ postchallenge, 3 fish per replicate were euthanized with a lethal dose of tricaine methanesulfonate (MS-222; $300 \mathrm{mg} \mathrm{l}^{-1}$ ) before the sinistral and dextral anteriormost gill arches were excised. Skin samples comprised $0.5 \mathrm{~cm}^{2}$ caudal patches excised with a scalpel and taken at identical sampling intervals. To quantify adhered cells of Flavobacterium columnare, gill and skin samples from 3 individual fish were pooled, weighed, and homogenized into $500 \mu \mathrm{l}$ of Sheih broth. Ten-fold dilutions from gill and skin slurries were made in Shieh broth: $100 \mu \mathrm{l}$ of suspension was spread onto Shieh medium agar plates in triplicate and incubated at $26^{\circ} \mathrm{C}$ for $48 \mathrm{~h}$. F. columnare counts (FC) based on typical yellow and rhizoid colonies were determined and expressed as the average number of $\mathrm{CFU}$ $\mathrm{g}^{-1}$ of tissue or $\log \mathrm{CFU} \mathrm{g}{ }^{-1}$ tissue. From each sampling time, 10 randomly selected putative $F$. columnare colonies were purified and confirmed as $F$. columnare by specific PCR (Welker et al. 2005).

Electron microscopy. Samples for scanning electron microscopy (SEM) were taken at $0.5 \mathrm{~h}$ post-challenge in Expt 1. Channel catfish fingerlings (3 per treatment) were euthanized as described in the previous subsection before immersion in $10 \%$ neutral buffered formalin for $48 \mathrm{~h}$. Gill arches were excised using fine forceps and scissors, gradually dehydrated in a graded series of ethanols using an automated tissue processor, transferred from $100 \% \mathrm{EtOH}$ to a 50:50 (v:v) of $100 \% \mathrm{EtOH}$ and hexamethyldisilazane (HMDS) for $1 \mathrm{~h}$, transferred to and left in HMDS for $1 \mathrm{~h}$, removed from HMDS and 
air-dried for $3 \mathrm{~h}$, mounted on metal stubs using 2-sided sticky tape, and sputter coated with $15 \mathrm{~nm}$ of goldpalladium.

Statistical analysis. Differences in CFU $\mathrm{g}^{-1}$ tissue within each experiment were compared using a repeated measures ANOVA procedure in the Statistical Analysis System, SAS 9.1.3 (SAS Institute). A significance level of 0.05 was accepted.

\section{RESULTS}

\section{Post-challenge bacteriological examination of channel catfish tissues}

No fish examined before challenge was positive for Flavobacterium columnare. Table 1 summarizes FC obtained from catfish gill and skin samples during Expt 1. FCs were on the order of $10^{3} \mathrm{CFU} \mathrm{g}^{-1}$ of skin in both ARS-1- and BGFS-27-challenged catfish at 0.5 and $1 \mathrm{~h}$ post-challenge. At $6 \mathrm{~h}$ post-challenge, FCs were not detected in skin samples from any tested fish. Flavobacterium columnare cells adhered to gill $\left(\sim 10^{6} \mathrm{CFU}\right.$ $\left.\mathrm{g}^{-1}\right)$ significantly better than to skin $\left(\sim 10^{3} \mathrm{CFU} \mathrm{^{-1 }}\right)$. Thirty min post-challenge $>10^{6} \mathrm{CFU} \mathrm{g}^{-1}$ of gill were counted in ARS-1- and BGFS-27-challenged fish. However, at $1 \mathrm{~h}$ post-challenge FC in ARS-1 infected fish were significantly higher than in fish challenged with the BFGS-27 strain. Six h post-challenge, FC in ARS-1 infected fish were reduced by 2 orders of magnitude. Differences between both strains at $6 \mathrm{~h}$ postchallenge were not significant. At 12 and $24 \mathrm{~h}$ postchallenge, the numbers of BFGS-27 cells from gill

Table 1. Flavobacterium columnare. Mean $( \pm \mathrm{SE})$ F. columnare cells (as CFU g ${ }^{-1}$ tissue) detected by bacteriological examination of channel catfish Ictalurus punctatus challenged with F. columnare during Expt 1. ND: not detected

\begin{tabular}{|c|c|c|}
\hline Time (h) & Skin & Gill \\
\hline Pre-challenge & ND & ND \\
\hline \multicolumn{3}{|c|}{ Post-challenge with ARS-1 } \\
\hline 0.5 & $1.1 \pm 2.0 \times 10^{3}$ & $1.4 \pm 2.3 \times 10^{6}$ \\
\hline 1 & $2.0 \pm 3.2 \times 10^{3}$ & $2.5 \pm 5.3 \times 10^{6}$ \\
\hline 6 & ND & $1.2 \pm 1.5 \times 10^{4}$ \\
\hline 12 & ND & $1.3 \pm 1.6 \times 10^{3}$ \\
\hline 24 & ND & $7.5 \pm 1.8 \times 10^{1}$ \\
\hline \multicolumn{3}{|c|}{ Post-challenge with BGFS-27 } \\
\hline 0.5 & $5.7 \pm 2.5 \times 10^{3}$ & $2.0 \pm 3.8 \times 10^{6}$ \\
\hline 1 & $1.2 \pm 3.2 \times 10^{3}$ & $3.1 \pm 3.2 \times 10^{5 \mathrm{a}}$ \\
\hline 6 & ND & $6.0 \pm 2.0 \times 10^{3}$ \\
\hline 12 & ND & $8.6 \pm 1.2 \times 10^{3 \mathrm{a}}$ \\
\hline 24 & ND & $6.8 \pm 1.0 \times 10^{3 \mathrm{a}}$ \\
\hline
\end{tabular}

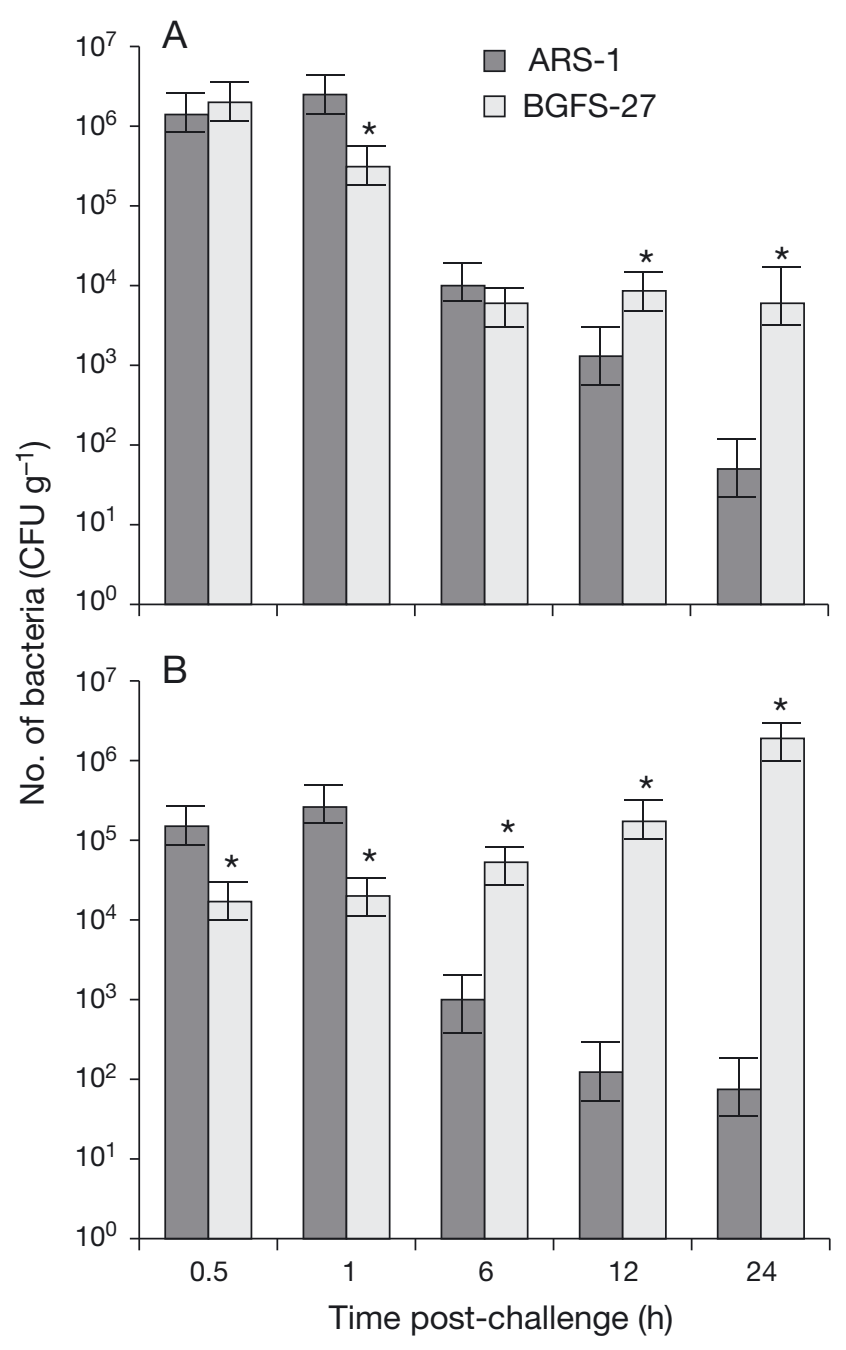

Fig. 1. Flavobacterium columnare. Mean $( \pm \mathrm{SE})$ number of cells of adhered to channel catfish Ictalurus punctatus gill during the time course of the study. Results from (A) Expt 1 and (B) Expt 2. Cell counts are colony forming units (CFU) per gram of tissue displayed on a logarithmic scale. ARS-1 is a genomovar I strain, and BGFS-27 is a genomovar II strain. *Significantly different $(p<0.05)$ data when both F. columnare strains were compared

samples were higher than those from ARS-1. Fig. 1 shows colony counts for $F$. columnare in channel catfish over time for Expts 1 and 2. A similar trend was observed in both experiments: ARS-1 adhered to gill epithelium in higher numbers than BGFS-27 during the first 0.5 to $1 \mathrm{~h}$. Ultimately, ARS-1 cells of F. columnare were cleared from gill, and only residual cells $\left(<100 \mathrm{FC} \mathrm{g}^{-1}\right)$ were detected at $24 \mathrm{~h}$. However, although BGFS-27 numbers were originally lower, these cells persisted in gill at higher numbers than ARS-1. Onset of columnaris disease using our infection model occurs from 24 to $48 \mathrm{~h}$ post-challenge; thus the variation observed between Expts 1 and 2 was considered normal. 


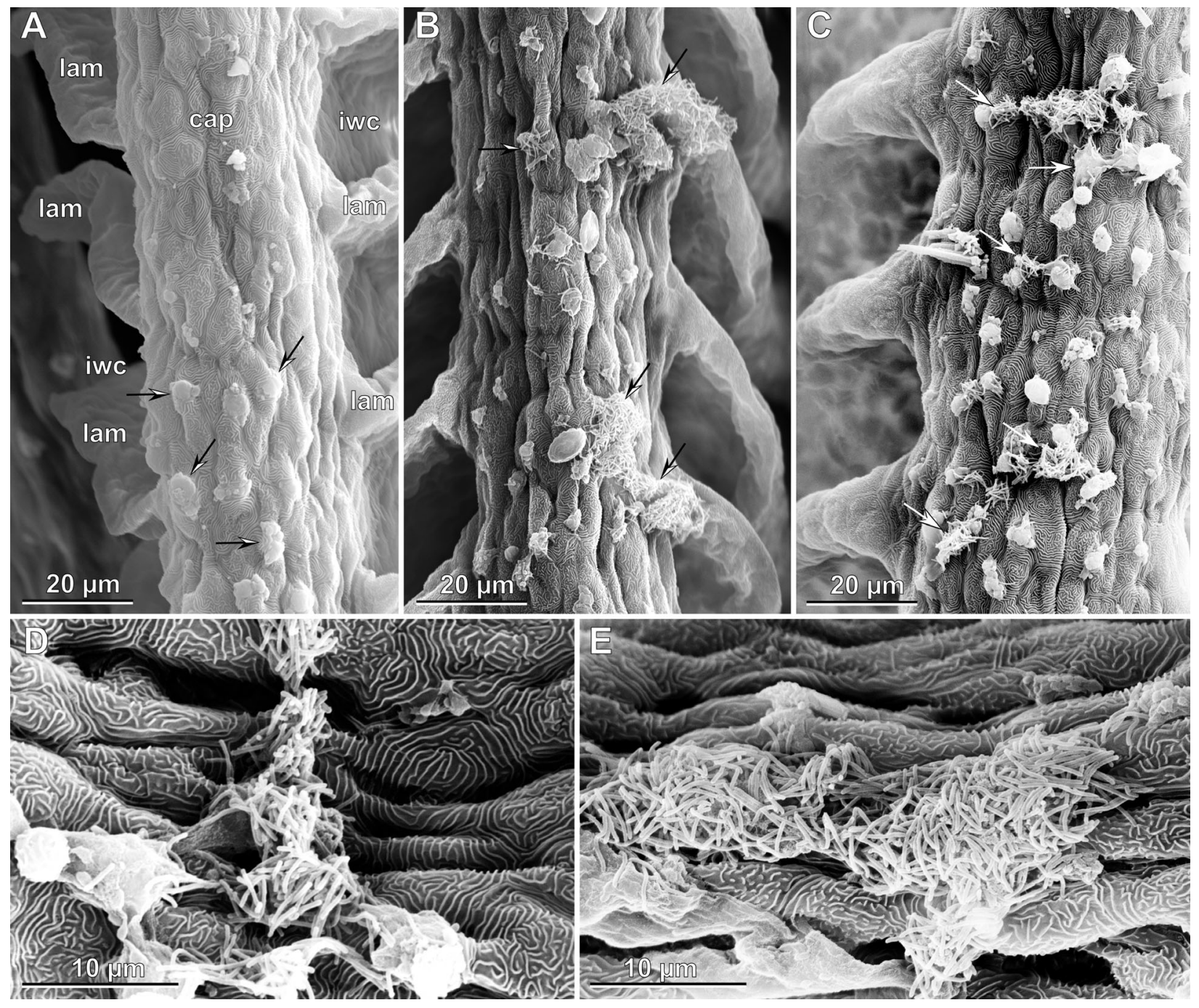

Fig. 2. Ictalurus punctatus. Gill of channel catfish. (A) Control, showing distribution of lamellae (lam) and interlamellar water channels (iwc) flanking the capping tissue (cap) of the gill filament. Arrows indicate the location of mucus exudate on the capping tissue of the gill filament. (B,C) Aggregates of adhered rod-shaped bacteria (arrows) presumed to be Flavobacterium columnare: (B) strain BGFS-27, (C) strain ARS-1. (D,E) Higher magnification view of an aggregate of cells adhered to gill: (D) strain BGFS-27, (E) strain ARS-1

\section{Scanning electron microscopy}

Gill of control channel catfish appeared normal, and a thorough search of the sampled gill arches and filaments from those control fish failed to locate a bacterial cell (Fig. 2). The capping tissue of the gill filament had a normal epidermis comprising intact epidermal cells ornamented with well-defined microridges and accompanying mucus pores with associated mucus exudate (Fig. 2A). Flanking each gill filament were normal, regularly-spaced, equally-sized gill lamellae having a smooth-surfaced respiratory epithelium (Fig. 2A). Flanking lamellae enclosed interlamellar water channels that were devoid of tissue debris or aggregates, of bacterial cells. Regarding bacterial-challenged gill samples, qualitatively no difference between strains was observed in the numbers of adhered bacterial cells per gill arch at $0.5 \mathrm{~h}$ post-challenge. As with controls, the basic structural integrity of the gill filament and lamellar respiratory epithelium was intact and appeared normal, except that rod-like bacteria presumed to be Flavobacterium columnare were localized on the surface of each gill filament's capping tissue. Interestingly, no bacterial cell was observed within an interlamellar water channel or adhered to the surface of a lamella. Moreover, the adhered rod-shaped bacterial cells appeared to be aggregated rather than evenly distributed across the gill epithelium (Fig. 2B-E). 


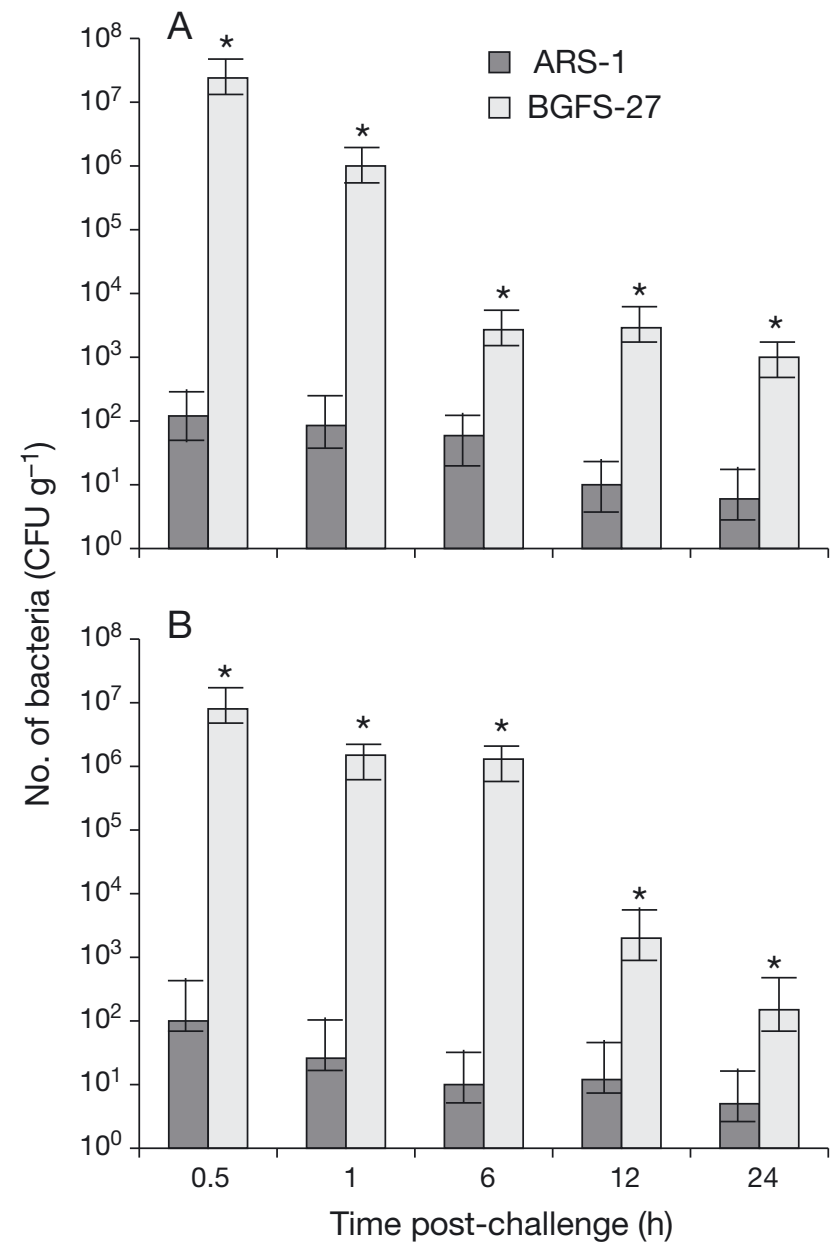

Fig. 3. Flavobacterium columnare. Mean $( \pm \mathrm{SE})$ number of cells adhered to gill of zebrafish Danio rerio during the time course of the study. Results from (A) Expt 3 and (B) Expt 4. See Fig. 1 for further explanations

\section{Flavobacterium columnare adhesion to zebrafish}

No zebrafish was positive for Flavobacterium columnare prior to challenge. Due to the low number of $F$. columnare cells detected in channel catfish skin, adhesion to zebrafish skin was not evaluated. BGFS-27 cells adhered to zebrafish gill at a much higher rate than ARS-1 cells. High FCs $\left(>10^{7}\right.$ CFU g $\left.{ }^{-1}\right)$ were recovered from BGFS-27-infected fish (Fig. 3A); whereas, $100 \mathrm{CFU} \mathrm{g}^{-1}$ were obtained from ARS-1-challenged fish $0.5 \mathrm{~h}$ post-challenge. Statistically significant $(p<0.05)$ differences existed between strains at all sampling points in Expts 3 and 4 (Fig. 3). Colony counts from BGFS-27 decreased over time although remained $>100 \mathrm{CFU} \mathrm{g}^{-1} 24 \mathrm{~h}$ post-challenge. No clear sign of columnaris disease was observed in zebrafish throughout the experiment.

\section{DISCUSSION}

Mucus is the first physical-immunological barrier encountered by a bacterium during the initial steps of colonization and invasion of a fish host. Fish mucus contains a variety of antimicrobial compounds such as antibacterial peptides, lysozyme, proteases, and antibodies (Ellis 1999) that may protect underlying epidermal cells from bacterial colonization via inhibition of bacterial adhesion to epithelial cells (Beachey 1981). On the other hand, bacteria possess attachment mechanisms like adhesins that have a high affinity for some components of fish mucus. Many bacterial adhesins contain carbohydrate-recognition domains (such as lectins) that bind to oligosaccharides present in mucus glycoproteins or glycolipids. Specifically, Flavobacterium columnare adheres to gill mucus by a lectinmediated interaction (Decostere et al. 1999c). Klesius et al. (2008) recently proved a positive chemotactic response by F. columnare towards channel catfish mucus. Their results highlighted the fact that cells of $F$. columnare prefer skin and gill mucus more than intestinal mucus, which seems to correlate well with typical manifestation of columnaris disease as an external infection of skin and gill.

Several studies have evaluated adhesion of high and low virulence strains of Flavobacterium columnare to host tissues (Decostere et al. 1999a, Nematollahi et al. 2003, Kunttu et al. 2009), but to our knowledge this is the first study comparing strains from both genomovars. Our in vivo results showed significantly different attachment to channel catfish gill by F. columnare strains from different genomovars. Both strains adhere equally well to catfish gill, but only BGFS-27 persisted over time (previous studies have shown that this strain is particularly virulent towards catfish). At time 0 , both strains showed a similar affinity for catfish gill, but BGFS-27 levels remained higher, seemingly multiplied in gill, and eventually appeared to bring about signs of columnaris disease in those fish, thus providing evidence that adhesion of $F$. columnare cells to gill in channel catfish is alone insufficient to elicit signs of columnaris disease. Hence, attachment, although necessary for invasion, cannot be directly correlated with virulence of $F$. columnare. Our in vivo results could explain discrepancies among various research laboratories conducting adhesion studies with $F$. columnare where only one time point was assayed (Decostere et al. 1999c, Kunttu et al. 2009). Channel catfish reduced the number of gill-adhered genomovar I cells by 4 orders of magnitude. Reduction of genomovar II cells was less effective, and in Expt 2 some channel catfish showed signs of columnaris disease. The ability of $F$. columnare to persist in host tissues may be a better indicator of potential virulence. 
It should be noted that infection models for columnaris disease are difficult to standardize since one must rely on the ability of the bacterium to colonize the external surface of the host (injection models do not reproduce typical columnaris disease), and many factors such as water quality, host susceptibility and strain virulence come into play. In our laboratory, we can induce the acute form of columnaris disease quite consistently with fish showing signs of disease between 24 and $48 \mathrm{~h}$ post-challenge. However, in Expt 2, channel catfish started to show signs within the first $24 \mathrm{~h}$ postchallenge. To the best of our knowledge, conditions were comparable between Expts 1 \& 2 (water parameters, fish came from the same lot and bacterial strains were grown similarly), but clearly there are other factors in play that can change the fish susceptibility to Flavobacterium columnare.

Interestingly, the results of the present study highlight adhesion differences between strains of different genomovars of Flavobacterium columnare as well as previously described host-specific associations existing between genomovars and fish species (OlivaresFuster et al. 2007). F. columnare genomovar I strain ARS-1 failed to effectively adhere to zebrafish gill (<100 CFU g ${ }^{-1}$ ), but genomovar II strain BGFS-27 adhered to zebrafish gill at even higher levels than to channel catfish gill $\left(>10^{7} \mathrm{CFU} \mathrm{g}^{-1}\right)$. Numbers of BGFS27 decreased over time such that no sign of columnaris disease was observed (no multiplication of BGFS-27 occurred in gill during the study period). In our laboratory setting, signs of columnaris disease can be instigated in both fish species challenged with either genomovar, although genomovar II strains are more virulent in general (data not shown; for a similar study see Shoemaker et al. 2008). The significant difference in adhesion properties of ARS-1 and BGFS-27 to channel catfish and zebrafish gill could explain the correlation between genomovars and fish species that is observed among some wild fishes infected with $F$. columnare (Olivares-Fuster et al. 2007).

Our scanning electron microscopy observations of Flavobacterium columnare in gill of channel catfish functioned merely as confirmatory, direct evidence of the presence of bacteria adhered to the gill tissue of the challenged fish, and were complementary to the plate counts. Although we examined an insufficient number of samples to confidently comment on the finescale site specificity of adhered cells, we nevertheless find it noteworthy that cells of $F$. columnare were restricted to the capping tissue of the gill filaments at $0.5 \mathrm{~h}$ post-challenge, i.e. we did not observe a cell in another site. Moreover, these adhered cells were abundant near mucus pores of the gill filament, with few cells adhered to the epithelial surface between mucus pores. These observations of $F$. columnare in gill of channel catfish differed markedly from those of F. psychrophilum in gill of ayu Plecoglossus altivelis (Kondo et al. 2002). In that study, cells of F. psychrophilum were scattered across the capping tissue of the gill filament, surfaces of lamellae, and within interlamellar water channels of ayu at $0.5 \mathrm{~h}$ post-challenge (see Fig. 2 of Kondo et al. 2002). Cells were cleared from gill subsequently (see Figs. 3 to 5 of Kondo et al. 2002). As with F. psychrophilum, further ultrastructural studies are needed to understand site specificity and adhesion mechanisms of $F$. columnare, but our casual observations of $F$. columnare clustered about mucus pores certainly does not reject the notion of in vivo chemotaxis of $F$. columnare to catfish mucus.

Herein, we have demonstrated how Flavobacterium columnare cells, from both genomovars, adhered to channel catfish gill in high numbers within $1 \mathrm{~h}$ postchallenge. However, BGFS-27 (genomovar II) cells persisted at higher levels and for a longer duration. Clearly, additional virulence factors besides adhesins are required to colonize the host. Condroitin AC lyase activity is related to virulence, and highly virulent strains have a higher activity level of this degrading enzyme (Suomalainen et al. 2006). Other suggested virulence factors for $F$. columnare are proteases and other hydrolytic enzymes (Dalsgaard 1993). Further research is needed to confirm if all genomovar II strains are indeed more effective at colonizing gill of channel catfish than genomovar I strains.

Acknowledgements. We thank M. Miller (Advanced Microscopy \& Imaging Laboratory, Auburn University) for technical support and J. Newton (Veterinary School, Auburn University) for providing channel catfish fingerlings. This research was funded by the USDA-ARS/Auburn University Specific Cooperative Agreement 'Prevention of Diseases of Farmed Raised Fish', USDA-ARS CRIS Project No. 6420-32000-02200D, and Alabama Agricultural Experiment Station HATCH funds awarded to S.A.B., C.R.A., and E. Peatman (Auburn University).

\section{LITERATURE CITED}

Arias CR, Welker TL, Shoemaker CA, Abernathy JW, Klesius PH (2004) Genetic fingerprinting of Flavobacterium columnare isolates from cultured fish. J Appl Microbiol 97:421-428

Beachey EH (1981) Bacterial adherence: adhesins receptor interactions mediating the attachment of bacteria to mucosal surfaces. J Infect Dis 143:325-345

- Bernardet JF, Segers P, Vancanneyt M, Berthe F, Kersters K, Vandamme P (1996) Cutting a gordian knot: Emended classification and description of the genus Flavobacterium, emended description of the family Flavobacteriaceae, and proposal of Flavobacterium hydatis nom. nov. (Basonym, Cytophaga aquatilis Strohl and Tait 1978). Int J Syst Bacteriol 46:128-148

> Dalsgaard I (1993) Virulence mechanisms in Cytophaga psychrophila and other Cytophaga-like bacteria pathogenic 
for fish. Annu Rev Fish Dis 3:127-144

Decostere A, Haesebrouck F, Charlier G, Ducatelle R (1999a) The association of Flavobacterium columnare strains of high and low virulence with gill tissue of black mollies (Poecilia sphenops). Vet Microbiol 67:287-298

Decostere A, Haesebrouck F, Turnbull J, Charlier G (1999b) Influence of water quality and temperature on adhesion of high and low virulence Flavobacterium columnare strains to isolated gill arches. J Fish Dis 22:1-11

Decostere A, Haesebrouck F, Van Driessche E, Charlier G, Ducatelle R (1999c) Characterization of the adhesion of Flavobacterium columnare (Flexibacter columnaris) to gill tissue. J Fish Dis 22:465-474

Ellis AE (1999) Immunity to bacteria in fish. Fish Shellfish Immunol 9:291-308

Klesius PH, Shoemaker CA, Evans JJ (2008) Flavobacterium columnare chemotaxis to channel catfish mucus. FEMS Microbiol Lett 288:216-220

Kondo M, Kawai K, Kurohara K, Oshima SI (2002) Adherence of Flavobacterium psychrophilum on the body surface of the ayu Plecoglossus altivelis. Microbes Infect 4:279-283

Kunttu HMT, Suomalainen LR, Jokinen RI, Valtonen ET (2009) Flavobacterium columnare colony types: connection to adhesion and virulence? Microb Pathog 46:21-27

Moyer TR, Hunnicutt DW (2007) Susceptibility of zebra fish Danio rerio to infection by Flavobacterium columnare and F. johnsoniae. Dis Aquat Org 76:39-44

Nematollahi A, Decostere A, Pasmans F, Ducatelle R, Haesebrouck F (2003) Adhesion of high and low virulence Flavobacterium psychrophilum strains to isolated gill

Editorial responsibility: Julie Bebak, Auburn, Alabama, USA arches of rainbow trout Oncorhynchus mykiss. Dis Aquat Org 55:101-107

Olivares-Fuster O, Baker JL, Terhune JS, Shoemaker CA, Klesius PH, Arias CR (2007) Host-specific association between Flavobacterium columnare genomovars and fish species. Syst Appl Microbiol 30:624-633

Plumb JA (1999) Health maintainence and principal microbial diseases of cultured fish. Iowa State University Press, Ames, IA

Schneck JL, Caslake LF (2006) Genetic diversity of Flavobacterium columnare isolated from fish collected from warm and cold water. J Fish Dis 29:245-248

> Shoemaker CA, Arias CR, Klesius PH, Welker TL (2005) Technique for identifying Flavobacterium columnare using whole-cell fatty acid profiles. J Aquat Anim Health 17: $267-274$

Shoemaker CA, Olivares-Fuster O, Arias CR, Klesius PH (2008) Flavobacterium columnare genomovar influences mortality in channel catfish (Ictalurus punctatus). Vet Microbiol 127:353-359

Suomalainen LR, Tiirola M, Valtonen ET (2006) Chondroitin AC lyase activity is related to virulence of fish pathogenic Flavobacterium columnare. J Fish Dis 29:757-763

Triyanto K, Wakabayashi H (1999) Genotypic diversity of strains of Flavobacterium columnare from diseased fishes. Fish Pathol 34:65-71

- Welker TL, Shoemaker CA, Arias CR, Klesius PH (2005) Transmission and detection of Flavobacterium columnare in channel catfish Ictalurus punctatus. Dis Aquat Org 63:129-138

Submitted: November 18, 2010; Accepted: May 2, 2011 Proofs received from author(s): September 6, 2011 